\title{
HUBUNGAN ANTARA PERSEPSI REMAJA TERHADAP KEBERFUNGSIAN KELUARGA DENGAN KEMATANGAN EMOSI PADA REMAJA AKHIR
}

\author{
Pebby Ayu Ramadhany \\ Triana Noor Edwina Dewayani Soeharto \\ Metty Verasari \\ Ramadhanypebby@gmail.com \\ Fakultas Psikologi Universitas Mercu Buana Yogyakarta
}

\begin{abstract}
Abstrak
Penelitian ini bertujuan untuk mengetahui hubungan antara persepsi remaja terhadap keberfungsian keluarga dengan kematangan emosi pada remaja akhir. Hipotesis yang diajukan dalam penelitian ini adalah ada hubungan positif antara persepsi remaja terhadap keberfungsian keluarga dengan kematangan emosi pada remaja akhir. Karakteristik subjek yakni : remaja berusia 16-18 tahun dan tinggal bersama orang tua. Jumlah subjek dalam penelitian sebanyak 93 subjek. Data penelitian di ungkap dengan Skala McMaster Family Assessment Device (FAD) yang disusun oleh Epstein,dkk (1983) untuk mengungkap persepsi remaja terhadap keberfungsian keluarga dan Skala Kematangan Emosi untuk mengungkap kematangan emosi. Analisis data dilakukan dengan teknik korelasi Product Moment dari Karl Pearson dengan menggunakan bantuan aplikasi SPSS 16. Berdasarkan analisis data antara variabel persepsi remaja terhadap keberfungsian keluarga dengan kematangan emosi pada remaja akhir diperoleh diperoleh koefisien ( $r x y)$ sebesar $0,546(p<0,01)$ sehingga hipotesis yang diajukan dapat diterima. Hal ini menunjukan bahwa adanya hubungan positif antara persepsi remaja terhadap keberfungsian keluarga dengan kematangan emosi pada remaja akhir.

Kata kunci: persepsi remaja, keberfungsian keluarga, kematangan emosi, remaja akhir
\end{abstract}

\begin{abstract}
This research aims to know the existence the relationship between perceptions of adolescents towards family functioning with emotional maturity in late adolescents. The hypothesis presented in this study is a positive relationship between perceptions of adolescents towards family functioning with emotional maturity in late adolescents. Research done on 93 students in SMA 1 Kretek. The characteristics of the subject is a adolescents of $16-18$ years old and living with parents. Total number of subjects is 92 subjects. Research data reveals the scale of the McMaster Family Assessment Device (FAD) compiled by Epstein, et al (1983) to reveal the adolescent perception of the family function and the scale of emotional maturity to reveral the emotional maturity. Data analysis was done with the technique correlation of Product Moment with the help of SPSS 16 applications. Based on the data analysis between variable perceptions of adolescents towards family functioning with emotional maturity in late adolescents obtained coefficient $(r x y)$ of $0.546(p<0.01)$ so the hypothesis proposed is acceptable. It is shown that the existence of a positive the relationship between perceptions of adolescents towards family functioning with emotional maturity in late adolescents. As positive as perceptions of adolescents
\end{abstract}


towards family functioning increase means the emotional maturity in late adolescents will be higher. Otherwise, as negaitive as perceptions of adolescents towards family functioning increase means the emotional maturity in late adolescents will be lower. Donations of adolescents perception towards the family functioning with emotional maturity in late adolescents of $29.8 \%$ means $70.2 \%$ is affected by other factors that are not involved in this research. adolescent

Keywords: perception of adolescents, family functioning, emotional maturity, late

\section{PENDAHULUAN}

Masa remaja merupakan puncak emosionalitas, yaitu perkembangan emosi yang tinggi. Pada usia remaja awal, perkembangan emosinya menunjukan sifat yang sensitif dan reaktif yang sangat kuat terhadap berbagai situasi atau sosial, emosinya bersifat negatif. pada remaja akhir, mereka sudah mampu untuk mengendalikan emosinya (Rochmah, 2005). Hurlock (dalam Nurihsan dan Agustin, 2011) mengatakan bahwa pada remaja akhir tidak meledakkan emosinya dihadapan oranglain tetapi menunggu saat dan tempat yang lebih tepat untuk mengungkapkan emosinya dengan cara-cara yang lebih diterima.

Remaja akhir adalah remaja yang berusia 16 sampai 18 tahun yang dalam rentang usia ini terjadi proses penyempurnaan pertumbuhan fisik dan perkembangan aspek-aspek psikis yang arahnya adalah kesempurnaan kematangan (Hurlock, 2004). Al-Mighwar (2011) mengatakan bahwa remaja akhir jarang memperlihatkan kemarahan, kesedihan, dan kecewa sebagaimana terjadi pada remaja awal karena remaja akhir telah memiliki kemampuan pikir dan kemampuan menguasai segala perasaannya dalam menghadapi berbagai kekecewaan atau hal-hal lain yang mengakibatkan kemarahan.

Al-Mighwar (2011) mengatakan bahwa permasalahan pada remaja akhir timbul jika terjadi penyimpangan dari ciri-ciri remaja akhir. Ciri-ciri dari remaja akhir yaitu telah menunjukan kestabilan emosi dan lebih tenang perasaannya. Remaja yang memberikan reaksi emosi secara stabil, tidak berubah-ubah dari satu emosi atau suasana hati ke suasana hati yang lain dikatakan telah mencapai kematangan emosi (Hurlock dalam Nurihsan dan Agustin, 2011).

Berdasarkan penelitian yang dilakukan oleh Astuti (2010) yaitu sebagian besar siswa kelas sebelas di sekolah Menengah Atas Negeri Kabupaten Sleman Yogyakarta memiliki tingkat kematangan emosi yang sedang dan rendah. Selain itu, penelitian yang dilakukan oleh Rizqi (2011) pada siswa-siswi SMA Negeri 11 Bekasi dapat dilihat bahwa dari 60 responden terdapat 12 responden (20 \%) memiliki skor kematangan emosi yang masuk dalam kategori rendah, 42 responden (70 \%) masuk dalam kategori sedang dan 6 responden (10\%) masuk kategori tinggi. Berdasarkan hasil penelitian yang dilakukan oleh Astuti dan Rizqi dapat dilihat bahwa kematangan emosi yang dimiliki oleh remaja berada pada kategori sedang dan rendah. 
Hurlock (2004) mengatakan kematangan emosi dapat dicapai bila remaja memperoleh gambaran tentang berbagai kondisi yang dapat mengakibatkan reaksi emosional. Caranya antara lain dengan membicarakan berbagai masalah pribadinya dengan oranglain dan juga remaja harus belajar bagaimana menyalurkan emosinya (Al-Mighwar, 2011). Individu yang telah mencapai kematangan emosi dapat diidentifikasikan sebagai individu yang dapat menilai situasi secara kritis terlebih dahulu sebelum bertindak, tidak lagi bereaksi tanpa berpikir sebelumnya seperti anak-anak atau orang yang tidak matang emosinya (Hurlock, 2004). Kematangan emosi pada remaja adalah bila remaja akhir usia 16 sampai 18 tahun. individu telah dapat mengendalikan emosinya sehingga dapat berpikir secara matang, baik dan obyektif.

Ciri-ciri kematangan emosi menurut Walgito (2004) yaitu: dapat menerima baik keadaan dirinya maupun keadaan orang lain sesuai dengan keadaan obyektifnya. Tidak bersifat impulsive, akan merespon stimulus dengan cara berfikir baik, dapat mengatur pikirannya untuk memberikan tanggapan terhadap stimulus yang mengenainya. Mampu mengontrol emosi dan mengekspresikan emosinya dengan baik. Bersifat sabar, penuh pengertian dan pada umumnya cukup mempunyai toleransi yang baik. Mempunyai tanggung jawab yang baik, dapat berdiri sendiri, tidak mudah mengalami frustasi dan akan menghadapi masalah dengan penuh pengertian.

Terdapat beberapa faktor yang dapat mempengaruhi kematangan emosi, menurut Young (dalam Rachmawati, 2013) yaitu: faktor lingkungan yang mencakup lingkungan keluarga seperti keharmonisan keluarga dan keberfungsian keluarga dan lingkungan sosial, faktor individu meliputi kepribadian yang dimiliki setiap individu dan faktor pengalaman yang diperoleh individu. Faktor yang dipilih dalam penelitian ini adalah faktor keberfungsian keluarga. Faktor ini dipilih karena sejalan dengan pendapat Brook,dkk (dalam Santrock, 2003) yang menyatakan bahwa remaja yang berada dalam keluarga penuh dengan konflik dapat memicu kenakalan remaja, karena cenderung mengalami ketidakmampuan dalam mengendalikan emosi. Agar remaja tumbuh dan berkembang secara optimal terutama dalam hal kematangan emosi maka perlunya keluarga yang dapat menjalankan fungsinya dengan baik. Setiap remaja akan memiliki pemikiran yang berbeda-beda terhadap keberfungsian keluargannya tergantung bagaimana remaja memberikan penilaian mengenai situasi yang terjadi di keluarganya. Penilaian disini berhubungan dengan apa yang dilihat dan dirasakan oleh remaja secara subjektif. Dalam penelitian ini objek yang akan di persepsi remaja adalah keberfungsian keluarga. Remaja mempersepsi secara positif atau negatif terhadap keberfungsian keluarganya.

Persepsi menurut Sumanto (2014) diartikan sebagai suatu kesadaran dan penilaian individu akan adanya oranglain atau perilaku orang lain yang terjadi di sekitarnya. Menurut 
Rakhmat (2005) persepsi dibagi menjadi dua bentuk yaitu positif dan negatif. Keberfungsian keluarga menurut Lubow, Beevers, Bishop, dan Miller (dalam Herawaty dan Wulan, 2013) adalah mengacu pada bagaimana seluruh anggota dari suatu keluarga dapat berkomunikasi satu sama, melakukan pekerjaan secara bersama sama, dan saling bahu membahu dimana hal tersebut memiliki pengaruh bagi kesehatan fisik dan emosional antar anggota keluarga. Keberfungsian keluarga menurut The McMaster Model of Family Functioning (MMFF) diartikan sebagai suatu keadaan dalam keluarga dimana setiap unit dari keluarga mampu menjalankan dengan baik tugas-tugas dasar dalam kehidupan keseharian di keluarga yang berkaitan dengan pemecahan masalah, komunikasi, peran, respon afektif, keterlibatan afektif dan kontrol perilaku (dalam Epstein dkk, 2000). Keluarga menurut Setiono (2011) adalah kelompok orang yang ada hubungan darah atau perkawinan dan di dalamnya terdiri dari ibu, bapak dan anak-anaknya.

Berdasarkan uraian dari beberapa ahli dapat disimpulkan bahwa persepsi remaja terhadap keberfungsian keluarga adalah penilaian remaja tentang kemampuan keluarga (ibu, ayah dan anak-anaknya) dalam menjalankan fungsinya yang berkaitan dengan pemecahan masalah, komunikasi, peran, respon afektif, keterlibatan afektif dan kontrol perilaku.

Terdapat enam dimensi yang dapat mengungkap keberfungsian keluarga yang dikemukakan oleh MMFF (McMaster Model of Familiy Functioning) (dalam Epstein, 2000) yaitu, penyelesaian masalah, komunikasi, peran anggota keluarga, responsivitas keluarga, keterlibatan afektif dan kontrol perilaku dalam keluarga.

Jika remaja mempersepsi secara positif terhadap keberfungsian keluarganya maka kematangan emosi remaja akhir tinggi. Namun jika remaja mempersepsi negatif terhadap keberfungsian keluarganya maka kematangan emosi remaja akhir rendah.

Hipotesis yang diajukan dalam penelitian ini adalah ada hubungan positif antara persepsi remaja terhadap keberfungsian keluarga dengan kematangan emosi. Semakin positif persepsi remaja terhadap keberfungsian keluarga maka semakin tinggi kematangan emosi remaja. Namun sebaliknya, semakin negatif persepsi remaja terhadap keberfungsian keluarga maka semakin rendah kematangan emosi remaja.

\section{METODE PENELITIAN}

Metode penelitian yang digunakan menggunakan metode penelitian kuantitatif Subjek dalam penelitian ini adalah remaja berusia 16-18 tahun, menurut Hurlock (2004) yang dalam rentang usia ini terjadi proses penyempurnaan pertumbuhan fisik dan perkembangan aspekaspek psikis yang arahnya adalah kesempuranaan kematangan dan tinggal bersama orangtua, remaja yang tinggal bersama orangtua dan berada dalam pengawasan atau bimbingan orangtua 
akan menjadikan remaja yang matang, tanpa mengalami masalah yang mengarah pada perilaku delinkuen (Monks,dkk. 2006).

Pengumpulan data dalam penelitian ini mengunakan skala. Skala kematangan emosi yang merupakan modifikasi dari skala yang dibuat telah oleh Nurfalah (2012) yang mengacu pada teori Walgito (2004) dan Skala persepsi remaja terhadap keberfungsian keluarga mengacu McMaster Family Assessment Device (FAD) yang disusun oleh Epstein, dkk (1983) dan Kedua skala dalam penelitian ini menggunakan model Likert dengan memiliki 4 alternatif pilihan jawaban yaitu SS (Sangat Sesuai), S (Sesuai), TS (Tidak Sesuai) dan STS (Sangat Tidak Sesuai). Untuk aitem favorable diberi skor 4 untuk jawaban SS, 3 untuk jawaban S, 2 untuk jawaban TS dan 1 untuk jawaban STS. Untuk aitem unfavorable diberi skor 1 untuk jawaban SS, 2 untuk jawaban S, 3 untuk jawaban TS dan 4 untuk jawaban STS (Azwar, 2014).

Sebelum digunakan dalam penelitian ini skala diujicobakan dulu untuk melihat ketepatan dan kecermatan suatu alat ukur (validitas) dan kestabilan alat ukur (reliabel). Berdasarkan hasil uji coba pada skala kematangan emosi yang berjumlah 40 aitem, terdapat 32 aitem yang dinyatakan valid dan 8 aitem yang dinyatakan gugur dan koefisien reabilitas sebesar 0,879.

Pada skala persepsi remaja terhadap keberfungsian keluarga yang berjumlah 53 aitem, terdapat 44 aitem yang dinyatakan valid dan 9 aitem yang dinyatakan gugur dan koefisien reabilitas alpha sebesar 0,921 .

Data penelitian di analisis secara statistik dengan menggunakan analisis korelasi Product Moment dari Pearson.

\section{HASIL DAN PEMBAHASAN}

Berdasarkan hasil analisis secara statistik, diperoleh hasil sebagai berikut

\begin{tabular}{|l|l|l|l|}
\hline & $\begin{array}{l}\text { Persepsi Remaja } \\
\text { Terhadap Keberfungsian } \\
\text { Keluarga }\end{array}$ & Kematangan Emosi & Hasil \\
\hline Uji Normalitas & $\begin{array}{l}\text { KS-Z }=0,079 \\
\mathrm{Sig}=0,199\end{array}$ & $\begin{array}{l}\text { KS-Z }=0,083 \\
\mathrm{Sig}=0,128\end{array}$ \\
\hline Uji Linieritas & $\begin{array}{l}\mathrm{F}=42,886 \\
\mathrm{Sig}=0,000\end{array}$ & Linier \\
\hline Uji Korelasi & $\begin{array}{l}\mathrm{R}=0,546 \\
\mathrm{Sig}=0,000\end{array}$ & Ada Korelasi \\
\hline $\begin{array}{l}\text { Sumbangan } \\
\text { Efektif }\end{array}$ & $29,8 \%$ & \\
\hline
\end{tabular}

Dengan demikian hipotesis penelitian ini diterima. Artinya semakin positif persepsi remaja terhadap keberfungsian keluarga maka semakin tinggi kematangan emosi remaja. Namun sebaliknya, semakin negatif persepsi remaja terhadap keberfungsian keluarga maka semakin rendah kematangan emosi remaja. 
Sumbangan efektif dari variabel persepsi remaja terhadap keberfungsian keluarga dengan variabel kematangan emosi pada remaja akhir diperoleh $r$ square $=0,298$, hal ini menunjukkan bahwa variabel persepsi remaja terhadap keberfungsian keluarga memiliki kontribusi sebesar 29,8 \% terhadap kematangan emosi pada remaja akhir dan sisanya 70,2 \% dipengaruhi oleh faktor-faktor lain yaitu lingkungan, individu dan pengalaman.

Hurlock (2004) menyebutkan bahwa kematangan emosi adalah apabila individu menilai situasi secara kritis terlebih dulu sebelum bereaksi secara emosional, tidak lagi bereaksi tanpa berfikir sebelumnya seperti anak-anak atau orang yang belum matang. Remaja yang memberikan reaksi emosi secara stabil, tidak berubah-ubah dari satu emosi atau suasana hati ke suasana hati yang lain dikatakan telah mencapai kematangan emosi (Hurlock dalam Nurihsan dan Agustin, 2011). Proses tercapainya kematangan emosi dipengaruhi oleh kondisi emosional lingkungannya terutama lingkungan keluarga. Jika lingkungan itu cukup kondusif maka remaja cenderung dapat mencapai kematangan emosionalnya (Rochmah, 2005). Berns (dalam Herawaty dan Wulan, 2013) mengatakan kewajiban suatu keluarga menjalankan fungsinya tersebut bertujuan agar anggota keluarga dapat terus bertahan dari generasi ke generasi. Keluarga yang baik adalah keluarga yang mampu menjalankan fungsinya dengan baik sehingga remaja terutama remaja akhir dapat tumbuh dan berkembang sesuai dengan tugas perkembangannya.

Persepsi remaja terhadap keberfungsian keluarga adalah penilaian remaja secara positif dan negatif terhadap kemampuan keluarga (ibu, ayah dan anak-anaknya) dalam menjalankan fungsinya yang berkaitan dengan pemecahan masalah, komunikasi, peran, respon afektif, keterlibatan afektif dan kontrol perilaku.

Remaja akan mempersepsi secara positif terhadap keberfungsian keluarganya jika remaja merasa dapat mendiskusikan tentang berbagai masalah yang dihadapi, memikirkan berbagai cara untuk menyelesaikan masalah tersebut dan menjalankan keputusan yang diambil untuk menyelesaikan masalah tersebut sehingga jika remaja sedang menghadapi konflik, remaja akan berusaha menyelesaikannya tanpa pertengkaran.

Selain itu, remaja mempersepsi bahwa keluarganya berfungsi jika remaja dan anggota keluarga yang lain mengetahui apa penyebab jika salah satu dari anggota keluarga sedang marah atau kesal, remaja merasa dapat dengan mudah untuk mengatakan apa yang dirasakan baik suka maupun tidak suka kepada setiap anggota keluarga dan dapat mengatakan secara langsung apa yang diinginkan atau tidak diinginkan oleh remaja kepada keluarganya sehingga remaja tidak akan bertengkar jika terjadi selisih paham atau perbedaan pendapat dengan temannya. 
Keluarga berfungsi dengan baik jika remaja mempersepsi positif dalam keluarganya terdapat pembagian tugas yang jelas dan semua anggota keluarga dapat melaksanakannya tanggung jawabnya dengan baik sehingga remaja akan belajar untuk bertanggung jawab pada dirinya sendiri. Jika lingkungan keluarga cukup kondusif, maka remaja cenderung dapat mencapai kematangan emosionalnya. Sebaliknya, jika remaja kurang dipersiapkan untuk memahami peran-perannya maka akan menimbulkan ketidaknyamanan emosionalnya (Rochmah, 2005)

Remaja yang merasa dapat merasakan kasih sayang dari keluarganya, remaja dapat menangis secara terbuka dihadapan anggota keluarga dan anggota keluarga saling menunjukan kelembutan antar anggota keluarga maka persepsi remaja terhadap keberfungsian keluarganya positif sehingga remaja dapat mencapai kematangan emosi yang ditunjukan dengan remaja akan memiliki empati dan toleransi dan tidak akan bersikap cuek pada sekitarnya. Hasil dari penelitian yang dilakukan oleh Sari (2012) mengatakan perhatian, kasih sayang, dan perasaan aman akan membantu individu menghadapi masalah-masalah tertentu dengan memperhatikan keseimbangan emosinya.

Remaja berpersepsi secara positif terhadap keberfungsian keluarganya apabila remaja sedang mengalami masalah maka anggota keluarga ikut membantu, remaja merasa diperhatikan oleh keluarganya dan saling mendukung satu sama lain sehingga remaja merasa dirinya diterima dan dapat belajar untuk menerima oranglain dan tidak akan merasa mudah putus asa. Sari (2012) menyatakan bahwa keluarga cukup dapat berfungsi dengan baik dan dapat diandalkan ketika remaja membutuhkan bantuan dan remaja cukup merasakan bantuan dan dukungan dari keluarga terhadap dirinya. Tanpa adanya dukungan dari keluarga, kemampuan emosional pada remaja akan berkembang lebih lambat (Brooks, 2011)

Remaja mempersepsi keberfungsian keluarganya secara positif apabila remaja mengetahui dan melaksanakan aturan-aturan yang berlaku di rumahnya. Dunst, Trivette dan Deal (dalam Fahrudin, 2012) mengatakan bahwa nilai, peraturan dan sistem kepercayaan yang jelas dapat menerangkan perilaku yang boleh dan tidak boleh diterima oleh keluarga. Dalam hal kematangan emosi, Astuti (2010) menyatakan bahwa kematangan emosi yang dimiliki oleh remaja akan dapat mengontrol emosi dan perilaku-perilaku negatif.

Berdasarkan hasil penelitian dapat diambil kesimpulan bahwa terdapat hubungan positif antara persepsi remaja terhadap keberfungsian keluarga dengan kematangan emosi pada remaja akhir. Hal tersebut menunjukkan bahwa semakin positif persepsi remaja terhadap keberfungsian keluarga maka semakin tinggi kematangan emosi remaja. Namun sebaliknya, semakin negatif persepsi remaja terhadap keberfungsian keluarga maka semakin rendah 
kematangan emosi remaja. kematangan emosi pada remaja akhir tidak mutlak dipengaruhi oleh persepsi remaja terhadap keberfungsian keluarga karena masih ada variabel lain yang mempengaruhi kematangan emosi pada remaja akhir.

\section{SIMPULAN}

Berdasarkan hasil analisis dan pembahasan, dapat ditarik kesimpulan, yaitu :

1. Ada hubungan positif antara persepsi remaja terhadap keberfungsian keluarga dengan kematangan emosi pada remaja akhir.

2. Korelasi positif tersebut mengandung pengertian bahwa semakin positif persepsi remaja terhadap keberfungsian keluarga maka semakin tinggi kematangan emosi pada remaja akhir dan sebaliknya semakin negatif persepsi remaja terhadap keberfungsian keluarga maka semakin rendah kematangan emosi pada remaja akhir.

3. Variabel persepsi remaja terhadap keberfungsian keluarga memiliki sumbangan 29,8\% terhadap kematangan emosi pada remaja akhir dan sisanya 70,2 \% dipengaruhi oleh faktor-faktor lain seperti lingkungan, individu dan pengalaman.

Berdasarkan hasil penelitian dan pembahasan, maka diajukan beberapa saran sebagai berikut :

1. Bagi remaja diharapkan dapat lebih terbuka dengan anggota keluarga mengenai masalah yang terjadi atau kejadian-kejadian yang terjadi di kehidupan sehari-hari agar remaja dapat menemukan penyelesaian masalah secara tepat dan keluarga akan saling mendukung tentang apa yang menjadi minat remaja.

2. Bagi orangtua diharapkan untuk membantu remaja agar memiliki kematangan emosi yang tinggi dengan menjadi keluarga yang berfungsi dengan baik dengan cara menjalin komunikasi yang baik antar anggota keluarga dengan remaja, mendiskusikan tentang masalah yang terjadi di keluarga, melibatkan remaja dalam pengambilan keputusan penting di keluarga, saling melaksanakan tanggung jawab peran masing-masing sehingga dapat melatih tanggung jawab bagi remaja, saling memberi dukungan satu sama lain dan saling menunjukan kasih sayang antar anggota keluarga sehingga remaja akan merasa dianggap dalam keluarga dan remaja akan menjadi dirinya sendiri. Remaja yang berada dalam pengawasan atau bimbingan orangtua akan menjadikan remaja yang matang khususnya secara emosi.

3. Bagi peneliti selanjutnya yang memiliki minat meneliti hal yang sama diharapkan dapat melibatkan variabel lainnya seperti lingkungan, individu dan pengalaman. 


\section{DAFTAR PUSTAKA}

Al-Mighwar,M. 2011. Psikologi Remaja Petunjuk Bagi Guru dan Orang tua. Bandung: CV. Pustaka Setia

Astuti,B. 2010. Model Bimbingan Dan Konseling Perkembangan Untuk Meningkatkan Kematangan Emosi Remaja. Makalah Penelitian

Azwar. 2014. Penyusunan Skala Psikologi (Edisi 2). Yogyakarta: Pustaka Pelajar

Brooks. 2011. The Process of Parenting. Edisi Kedelapan. Yogyakarta: Pustaka Pelajar

Epstein,NB, Bishop,DS, Keitner,GI, Ryan,CE \& Miller,IW. 1983. The McMaster Family Assesment Device. Journal of Marital and Family Therapy 9 (2) ; 171-180

Epstein,NB, Bishop,DS, Keitner,GI, Ryan,CE \& Miller,IW 2000. The McMaster Approach to Families: theory, assessment, treatment and research. Journal of Family Therapy 22 (2) ; $168-189$

Fahrudin. 2012. Keberfungsian Keluarga: Konsep Dan Indikator Pengukuran Dalam Penelitian. Informasi 17 (2) ; 75-81

Herawaty,Y. \& Wulan, R. 2013. Hubungan Antara Keberfungsian Keluarga Dan Daya Juang Belajar Berdasar Regulasi Diri Pada Remaja. Jurnal Psikologi 9 (2) ; 138-147

Hurlock. 2004. Psikologi Perkembangan: Suatu Pendekatan Sepanjang Rentang Kehidupan (edisi kelima). Alih Bahasa: Istiwidayanti, Soedjarwo, Sijabat R.M. Jakarta: Erlangga.

Monks,dkk. 2006. Psikologi Perkembangan: Pengantar Dalam Berbagai Bagiannya. Yogyakarta: Gajah Mada University Press

Nurfalah, U. 2012. Hubungan Antara Keberfungsian Keluarga Dengan Kematangan Emosi Pada Remaja. Skripsi. Yogyakarta: Program Studi Psikologi Fakultas Psikologi Dan Ilmu Sosial Budaya Universitas Islam Indonesia

Nurihsan,J.A \& Agustin,M. 2011. Dinamika Perkembangan Anak dan Remaja: Tinjauan Psikologi, Pendidikan, dan Bimbingan. Bandung : PT. Refika Aditama

Rachmawati,F. 2013. Hubungan Kematangan Emosi Dengan Konformitas Pada Remaja. Jurnal Fakultas Psikologi 2 (1)

Rakhmat,J. 2005. Psikologi Komunikasi. Bandung: PT. Remaja Rosdakarya.

Rizqi,MIT. 2011. Pengaruh Kematangan Emosi Terhadap Kecenderungan Perilaku Self Injury Pada Remaja. Skripsi. Jakarta: Program Studi Psikologi Fakultas Psikologi Universitas Islam Negeri Sarif Hidayatullah

Rochmah.E.Y. 2005. Psikologi Perkembangan. Yogyakarta: TERAS 
Santrock, JW. 2003. Adolescence: Perkembangan Remaja (edisi keenam). Alih Bahasa: Adelar dan Saragih. Jakarta: Erlangga.

Sari, IP. 2012. Hubungan Antara Keberfungsian Keluarga Dengan Kematangan Emosi Remaja Laki-Laki. Skripsi. Medan: Fakultas Psikologi Universitas Sumatra Utara

Sumanto. 2014. Psikologi Umum : Untuk Mahasiswa, Dosen dan Masyarakat Umum. Yogyakarta: CAPS (Center of Academic Publishing Service)

Walgito, B. 2004. Bimbingan Konseling Dan Perkawinan. Yogyakarta : Andi Offset. 